DOI: https://doi.org/10.34069/AI/2021.38.02.17

\title{
Conceptual foundations for social media in the restaurant business in the aftermath of the pandemic
}

\author{
Концептуальный базис социальных медиа в ресторанном бизнесе в условиях \\ последствий пандемии коронавируса
}

Accepted: March 31, 2021

\author{
Written by: \\ Kuzubov Alexey Alexeyevich ${ }^{56}$ \\ https://orcid.org/0000-0001-5631-7793 \\ SPIN-код: 3256-6820 \\ AuthorID: 823087 \\ Maksimenko Aleskandr Nikolaevich ${ }^{57}$ \\ https://orcid.org/0000-0003-3734-3085 \\ SPIN-код: 6610-2592 \\ AuthorID: 833345 \\ Eremenko Igor Anatolievich ${ }^{58}$ \\ https://orcid.org/0000-0001-5295-5827 \\ SPIN-код: 9921-4984 \\ AuthorID: 776832 \\ Bezuglova Margarita Nikolaevna ${ }^{59}$ \\ https://orcid.org/0000-0002-3403-3818 \\ SPIN-код: 4487-9356 \\ AuthorID: 760339
}

\begin{abstract}
The article examines the key problems, changes and restrictions in the development of the restaurant business during the coronavirus pandemic. The analysis of the results of a study by European scientists on the use of social networks in the restaurant business is carried out. The essence of social media marketing (SMM) as an effective tool for overcoming the temporary crisis of the restaurant business is characterized. The target market was segmented and the results analyzed. The analysis shows the target market breakdown of restaurant visitors by marital status and by age groups. The main reasons why restaurateurs do not plan to use social networks or have not yet initiated the use of social networks are considered. The study identified the impact of the coronavirus pandemic on the restaurant business and presented ways to overcome them. The importance of marketing use in social networks by restaurateurs is justified. Based on the results of the study, the main conclusions are presented on the feasibility of introducing certain measures in the restaurant
\end{abstract}

\begin{abstract}
Аннотация
В статье рассмотрены ключевые проблемы, изменения и ограничения в развитии предприятий ресторанного бизнеса в период пандемии коронавируса. Проведен анализ результатов исследований европейских ученых по использованию социальных медиа в ресторанном бизнесе. Охарактеризована сущность социального медиа-маркетинга (SMM) как действенного инструмента для преодоления временного кризиса в сфере ресторанного бизнеса. Проведена сегментация целевого рынка и проанализированы полученные результаты. Показано распределение целевого рынка посетителей ресторанов по семейному положению, распределение целевого рынка посетителей ресторанов по возрастным группам. Рассмотрены основные причины, по которым рестораторы не планируют использовать социальные медиа или еще не инициировали использования социальных медиа. В процессе исследования дана оценка последствий пандемии коронавируса для ресторанного
\end{abstract}

\footnotetext{
${ }^{56}$ Candidate of Economic Sciences, associate Professor of Economics, Don state Technical University, Russia.

${ }^{57}$ Candidate of Economic Sciences, associate Professor of Economics, Don state Technical University, Russia.

58 Candidate of Economic Sciences, associate Professor of Economics, Don state Technical University, Russia.

${ }^{59}$ Candidate of Economic Sciences, associate Professor of Economics, Don state Technical University, Russia.
} 
business to stabilize the financial situation, overcome the crisis and recoup the maximum production costs.

Key Words: advertising, communications, conceptual foundations, restaurant business, social media marketing.

\section{Introduction}

The restaurant business itself is quite complex. Opening a restaurant is not enough to earn money. Even at the best of times, $60 \%$ of restaurant startups will fail in the first year, and $80 \%$ in the first five ones.

The reasons for this high closure rate are numerous: changing consumer preferences, inappropriate placement, high rents, rapid employee turnover, and poor digital consumer experiences in the era of smartphones and apps.

All of these reasons are not new ones. They are constantly being researched, many scientific papers, articles and books have been written about them. But today a completely new threat has appeared, which in a matter of days has covered almost the entire planet. In late 2019 early 2020, the world was swept by the COVID19 virus epidemic. The economy has suffered and continues to suffer colossal losses, since the spread of the pandemic around the world caused not only disquietude among people, but also negatively affected almost all sectors of the economy, from manufacturing to the service sector.

The coronavirus recession has affected all industries, of which the restaurant business is the most visible and emblematic. Today the restaurant business is actively fighting to preserve its own vitality. Due to the coronavirus pandemic, most restaurant businesses around the world have been forced to close.

The restaurant business is facing an unprecedented crisis that will undoubtedly change the way businesses operate in this sector in the future. Restaurateurs all over the world, for whom the restaurant business is of value, today are forced to use all the key resources. In such бизнеса и представлены направления их преодоления. Обоснована значение применения социального медиа маркетинга рестораторами. По результатам исследования представлены основные выводы о целесообразности внедрение в ресторанный бизнес определенных мер для стабилизации финансового положения, выхода из кризисного состояния и окупаемости максимальных затрат на производство.

Ключевые слова: реклама, коммуникации, концептуальный базис, ресторанный бизнес, социальный медиа-маркетинг.

conditions, the issues of flexibility and speed of reaction of restaurant enterprises come to the fore, which ensures an adequate transformation of the business model of their activities in accordance with changes in business conditions. The new industrial landscape created by COVID19 is forcing the restaurant business to develop new creative mechanisms not only to maintain vitality, but also for development that would allow them to adapt to the new realities of the external environment.

\section{Literatura Review}

Leading world experts such as R. Ruggles, K. Hermkens, K. Jiyan are solving the problems of using social networks in the restaurant business. The following contemporary works highlight the main problems: (Hajli, 2014), «The impact of social media reviews on restaurant performance: The moderating role of excellence certificate» (Kim, Li, \& Brymer, 2016), «Putting a face on small businesses: Visibility, viability, and sustainability the impact of social media on small business marketing » (Taneja, \& Toombs, 2014), « Social media and human need satisfaction: Implications for social media marketing» (Zhu \& Chen, 2015), etc.

The works of these authors highlight the principles and foundations of marketing in the global network, the use of social media marketing in hotel and restaurant establishments, as in a special environment for promoting goods and services on the market, analyzing modern approaches to marketing management, exploring the specifics of using its individual tools.

At the same time, existing developments in the direction of justifying development strategies for restaurant business enterprises do not take into 
account the specifics of activities during the period of the new industrial landscape created by COVID-19.

\section{Methodology}

The study was carried out by methods of scientific analysis of the phenomenon under research, namely: the dialectical method of cognition, methods of analysis and synthesis, comparison, deduction and induction, methods of statistical analysis, methods of mathematical statistics, modeling, extrapolation, the method of idealization together with methodological methods of systematization, generalization, review and comparison, juxtaposition of scientific facts, abstraction. The research methodology is based on the theory of scientific knowledge and a systematic approach to the study of phenomena and processes. The results of scientific and creative comprehension of the achievements of foreign and domestic scientists in the field of social media in the restaurant business were also used.

Methods of formalization, modeling, induction and deduction, idealization and abstraction, factorial approach (in the study of the theoretical and methodological foundations of social media in the restaurant business, as well as in the study of foreign experience).

Methods of formalization, modeling, forecasting, a graphical method and a systematic approach (when developing a conceptual framework for marketing in social networks for the restaurant business in the context of innovative, digital and post-viral trends in economic transformation and comparative systematization of their position).

Statistical, monographic, historical, sociological, graphic methods, methods of economic analysis and the method of expert assessments, scenario analysis (in the segmentation of the target market of the restaurant business, development of recommendations for the use of social media in the restaurant business), as well as in the process of assessing the main reasons for the interaction of restaurateurs with social media).

\section{Results and Discussion}

The modern world faces problems that it has never faced. The consequences and losses due to the pandemic spreading are colossal. According to Meagher and Cheadle (2020), the most sensitive areas of business, on whose activities direct restrictions were imposed in connection with the quarantine measures realization, are:
1) entertainment and cultural institutions (theaters, cinemas, exhibitions, various entertainment events, fitness clubs, etc.) have from a complete stop to a drop in revenue by $50-80 \%$;

2) hotel and restaurant business, where the situation is almost the same, since restrictions are imposed on gathering people; by decision of the government, only food preparation and delivery to the customer is allowed;

3) travel services, which fell sharply during the quarantine period due to the closure of borders and interregional traffic;

4) the sphere of cosmetic services provision, where there is already a decrease in visitors by more than $50 \%$.

The formation and implementation of the restaurant business development strategy were usually based on a wide range of groups of factors, including scientific and technical, social, cultural and historical, economic, political and legal, international, natural and climatic, demographic (Osipov, Shashlo, \& Kuzubov, 2017). The COVID-19 epidemic and the sanitary measures realization have revealed a list of factors that have made significant changes and restrictions in the development of the restaurant business around the world.

This is mainly due to the fact that the restaurant business is a key component of the food industry, which in its essence and purpose is a natural socio-economic system and is a part of an intersectoral regional cluster that actively influences development of all sectors of the food complex of the state (Binsawad, 2020).

Daily traffic to restaurants around the world has significantly decreased compared to the same period in 2019 (Singh \& Verma, 2020).

But whatever the pandemic, it should be remembered that sooner or later this will end, and it is then that a real race for survival will begin for restaurants, in which all forces and resources must be mobilized as soon as possible in order to return lost customers and find new ones in order to overcome the consequences of downtime and recoup costs.

Those who cannot do it in the shortest possible time will simply close due to debt and bankruptcy.

Social networks are not a new concept, but rather a new form of interaction with people (Dimitriou $\&$ Abou, 2019). A Gallup survey found that $72 \%$ 


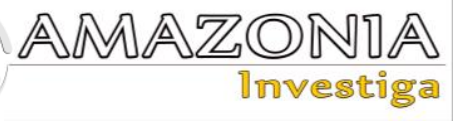

of adults use social media frequently during the day. The influence of social networks has changed the attitude of businesses towards their customers (Mullakhmetova, 2020). Business uses social networks to build relationships with their customers and achieve new prospects (Terenteva, Shashlo \& Kuzubov, 2017), E. N. Rudskaya, A. N. Maksimenko, L. V. Desyatnichenko (2019). Some consumers need certain information about products and services. Clients use social networks to give valuable advice to others and share experiences and information around the world (Shashlo, 2017). Social media platforms provide companies with the ability to interact with existing and potential customers and build special relationships. Business leaders use social networks to attract customers and interact with them, trying to influence sales and awareness (Lepkowska-White, Parsons \& Berg, 2019).

Social media has changed the digital media landscape, thereby influencing how organizations sell their products. Effective use of social media marketing is beneficial for both small and large businesses as it increases income, is more cost effective and efficient. The main advantage is that social media marketing is an inexpensive marketing tool to advertise and promote a product or service (Taha, 2019).

Social media is a dynamic process in any business. Social networks are a tool and strategy that require commitment and constant monitoring in all elements of the organization (Mullakhmetova, 2020). The biggest challenge for companies with regard to social media marketing is figuring out how and when to use it appropriately and effectively (Taha, 2019).

The results of European studies, presented in (Kim, Li \& Brymer, 2016), showed that the efficiency of a restaurant increases with an increase in the number of positive customer reviews on the Internet.

Restaurants using social media have the opportunity to gain trust of their consumers by developing relationships and allowing users to share their dining experiences with others. Consumers share not only thoughts, suggestions and comments about the services provided, but also photos. This helps restaurants to define their target market and deliver more targeted information to consumers (Petruk \& Shashlo, 2020).

In order to develop recommendations on the directions and feasibility of social networks using in the restaurant business as a tool to counter the consequences of COVID-19, and as part of this study, the target market was segmented and the results were analyzed. The main results are shown in Fig. 1-4.

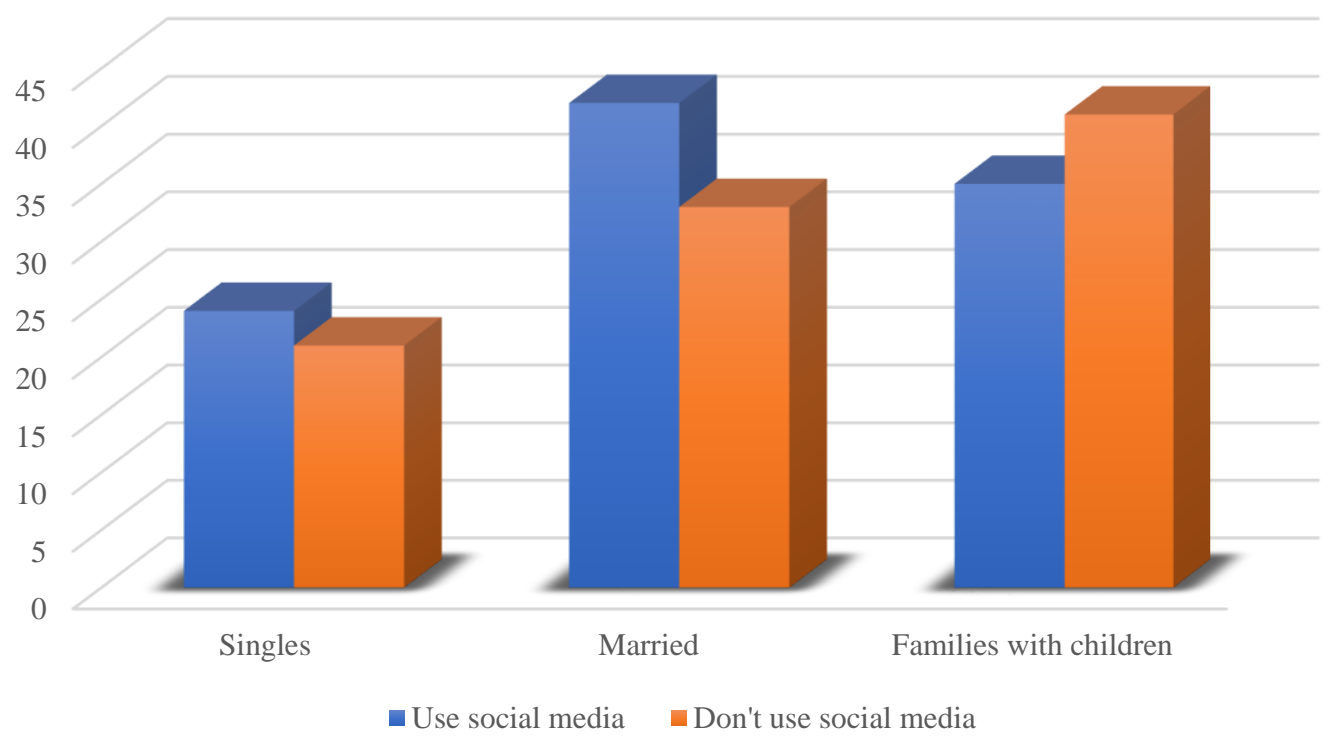

Figure 1. Distribution of the target market of restaurant visitors by marital status in $\%$. 
As shown in fig. 1, restaurants using social media primarily target married people, then married ones and then singles. On the contrary, restaurants which do not use social media are targeted families, then married people and singles.

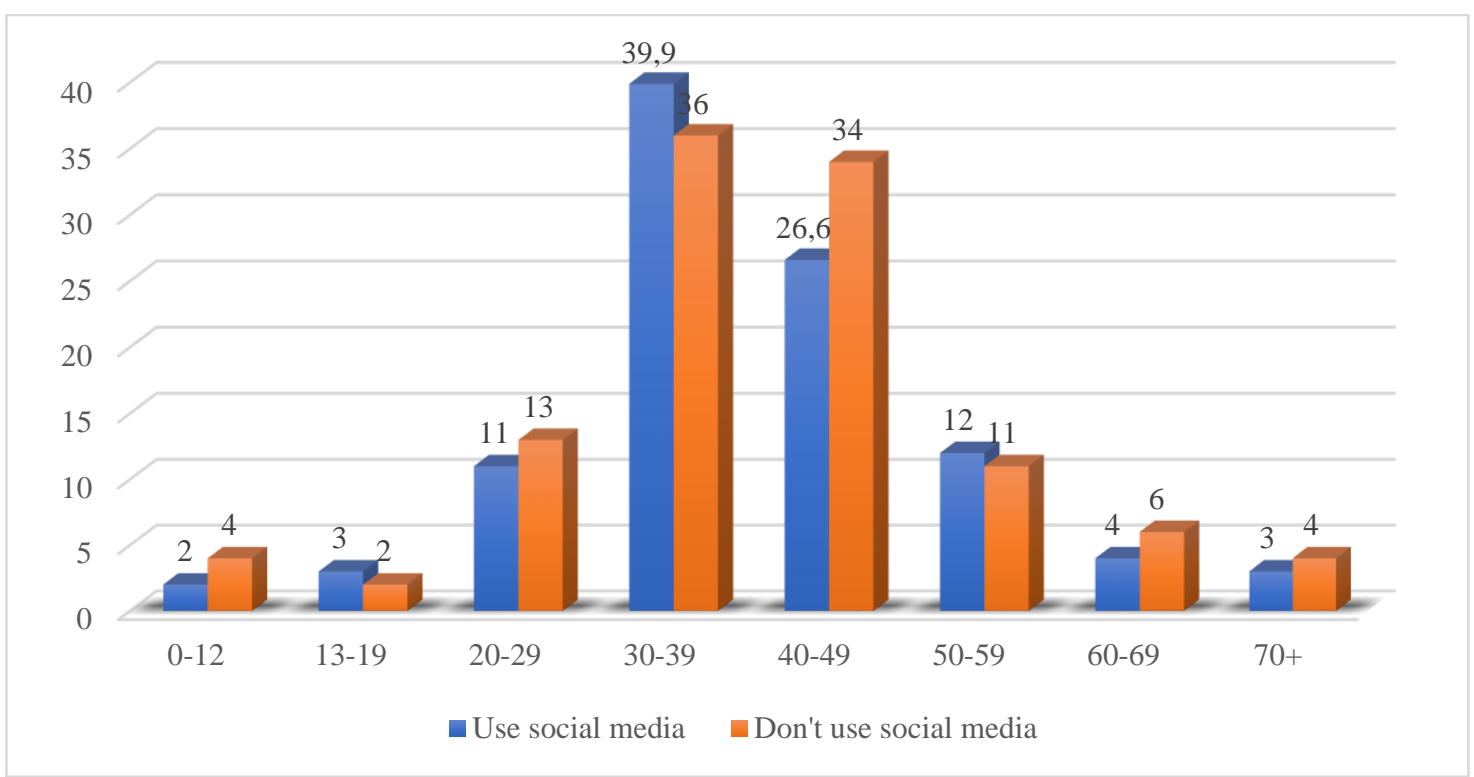

Figure 2. Distribution of the target market of restaurant visitors by age groups in $\%$.

The analysis of the target age groups of the market (Fig. 2) demonstrated that the age range from 30 to 39 years old is important for the use of social networks, and, of course, this age group uses social networks. But this indicator is universal for all restaurants, because the age range of 30-39 years for the restaurants using social networks is $39.9 \%$. The next most important segment is 40-49 years old with a specific weight of $26.6 \%$. These results are in line with the average age of Facebook and Instagram users.

Next, the authors analyzed distribution of the target market of social media users in compare to the total target market of restaurants by marital status and the distribution of the target market of social media users in compare to the total target market of restaurants by age group are analyzed (Fig. 3-4).

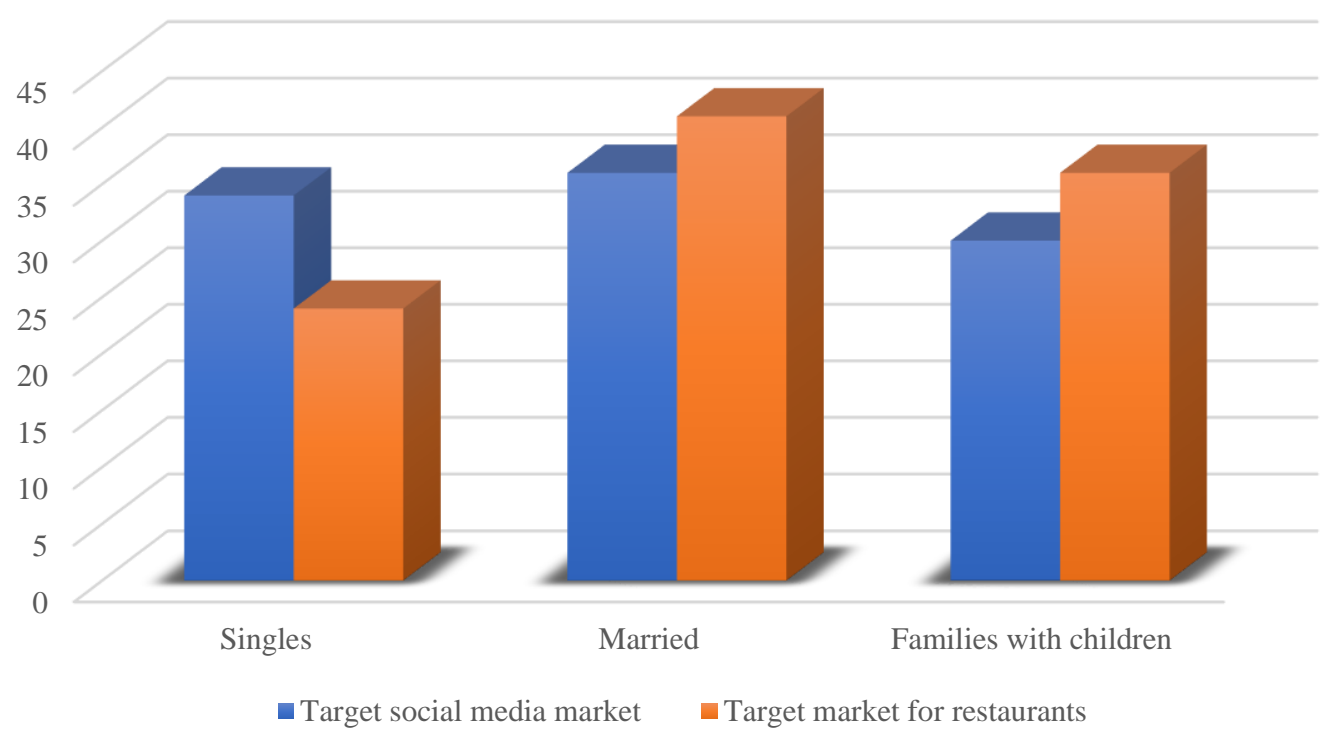

Figure 3. Distribution of the target market of social media users in compare to the total target market of restaurants by marital status in \% 
Restaurants that do not use social media give comparatively more weight to the younger (012) and older (60+) age groups, which may be related to the use of social media in these age groups. Social media efforts are geared more towards singles than couples and families, compared to the restaurant's target market as a whole (Figure 3).
The age of the target market for activity in social networks is 20-49 years old, the age range is usually below the target market for the restaurant as a whole (Fig. 4). This conclusion is consistent with the general idea that social networks are more actively used by young people (Melnik, 2020).

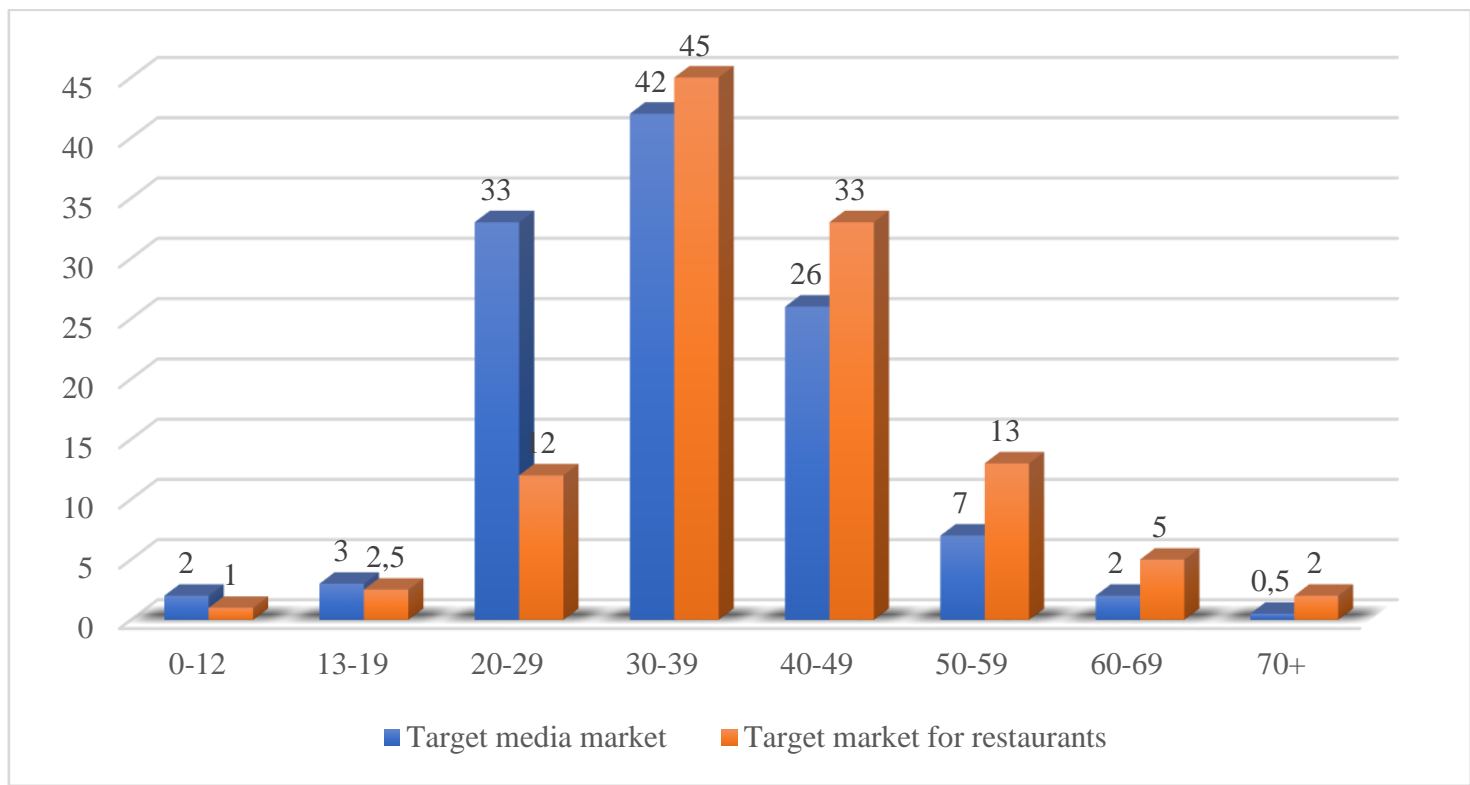

Figure 4. Distribution of the target market of social media users in compare to the total target market of restaurants by age group in $\%$.

This information enables restaurant owners to identify their target audience. For example, if it is a pizzeria, then it will be popular among the younger generation, because pizza is a fairly hearty and inexpensive food. Therefore, here it is necessary to make an effort to properly communicate with the young audience, involving them in the purchase.

And vice versa, when it comes to an expensive or even prestigious restaurant, it is more correct to focus on the age group - the $30+$ segment.

Consider the problem of some restaurants refusing to use social media.

According to (Hoferichter, 2018), a dozen restaurateurs said they did not plan to use social media for the foreseeable future, and another seventeen said they simply had not yet reached this level (the reasons given by both groups are shown in Table 1).

Table 1.

The main reasons for the interaction of restaurateurs with social networks.

\begin{tabular}{lll}
\hline The restaurateur's answer & No plans & Nonetheless to initiate \\
\hline Social media doesn't fit our restaurant concept & 5 & 3 \\
We are skeptical & 2 & 5 \\
Waiting for a brand or headquarters to initiate social media & 3 & - \\
use. & - & 3 \\
Lack of knowledge & - & 2 \\
We are currently working on the use of social media & 2 & 4 \\
Other & \\
\hline
\end{tabular}


Restaurateurs should also focus on an online marketing tool that involves promoting the restaurant product, the restaurant business itself and its brand through social media content created or updated by owners and visitors, namely social media marketing. (Social Media Marketing, SMM)

It is worth noting that SMM has its own specifics, which, in terms of its strategy and terminology, differ significantly from traditional marketing, but this is a full-fledged marketing.

Based on digital technologies, social media marketing has advantages such as instant audience response and its quick analysis, competitive intelligence and online monitoring of prices and competitors' actions, information analysis and analysis of audience reaction, types of advertising and ways to promote content.

According to the results of the study, it was found that many ways have been accumulated to create a development plan in social networks at the present stage of development of the restaurant business.

However, it should be noted that no matter what alternative method is used in the restaurant business, it should always be considered that the company is both the sender and the recipient of messages.

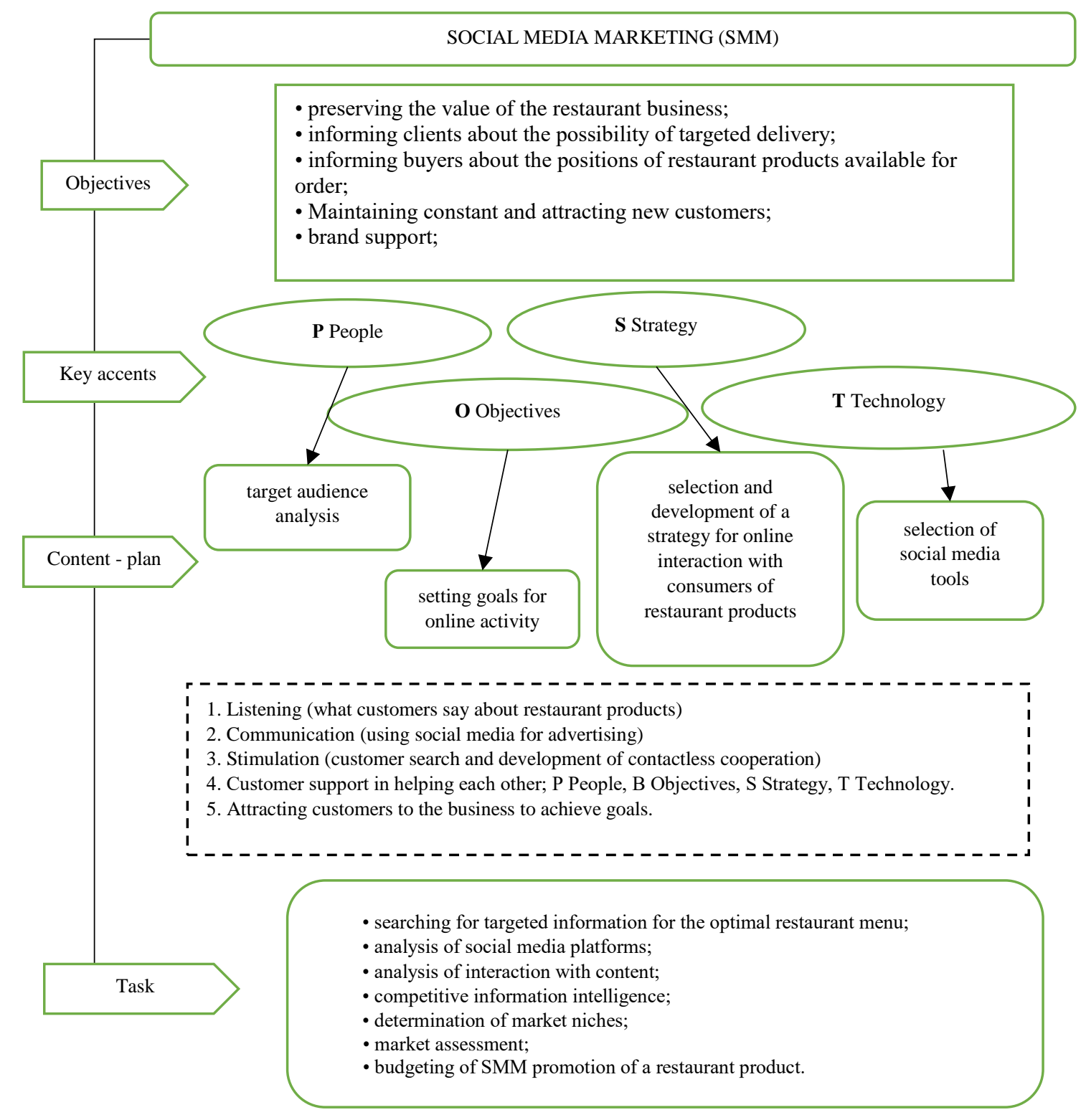

Figure 5. Conceptual framework for social media marketing for the restaurant business. 
The restaurant business as a sender of information seeks to convince, inform and entertain the target audience in order to attract new and gain regular customers. The restaurant business as a recipient adjusts its activities to the needs of the consumer.

The main goal of social media marketing is to shape the marketing message and identify ways to interact with the target audience.

European experts (DiPietro, Crews, Gustafson \& Strick, 2016) conducted a study in which they interviewed network owners who use social media and social media, and found that building customer relationships is the most significant advantage. They have defined a customer relationship management (CRM) system, which means that potential customers can provide and improve services according to their needs.

Based on the research results, the conceptual foundations of marketing in social networks of the restaurant business have been developed (Fig. 5).

It is based on a four-stage approach (POST method) and is focused on identifying key accents that should be taken into account when determining strategic vectors for the development of the restaurant business in the short term, when developing an effective marketing plan in social networks, interaction between business and customers (Zueva \& Safronov, 2018), Petrova, (2020).

The POST method (People, Objectives, Strategy, Technology) was proposed by Charlene Lee and J. Bernoff as an effective basis for developing social media strategy. Josh Bernoff, senior vice president of Research Group, believes that POST should be used when developing a set of SMM actions:

P: People - analysis of the target audience.

Developing an SMM strategy should start with researching existing or potential consumers and analyzing the social media platforms they use. At this stage, research and analytical activities are carried out and it is determined which types of online activities consumers prefer.

O: Objectives - defining clear goals. The firm must have clearly defined goals for its future online activities (these can be: online reputation management, increasing brand awareness, winning consumer attention, etc.). It should also not be forgotten that the overall goal of SMM for any campaign is to ensure the company's presence on social media.

S: Strategy - development of a strategy for interaction with consumers. For this stage of the implementation of the SMM development strategy, first of all, it is necessary to answer the question: "How exactly do you want to change your relationship with customers?"

There are five main strategies that most modern companies adhere to in the field of customer interaction:

1. Listening: examining what customers are saying about the company's products and services.

2. Speaking: Using social media to spread advertisements, ideas and thoughts to clients.

3. Incentives: finding clients and developing cooperative relationships.

4. Customer support by helping each other.

5. Attracting customers to the business to achieve goals and product design.

T: Technology is a set of social media tools. When forming the social media apparatus, conduct a thorough analysis of existing social media and their purpose, pay attention to consumer preferences when using certain social networks.

According to the results of the study, the conceptual basis of marketing in social networks of restaurant business is an integral complex, key POST accents, the content of the plan and tasks that ensure the process of managing restaurant business at all levels of the hierarchy into a single whole, creates the ability to keep vitality and retention of clients in the context of the pandemic.

\section{Conclusions}

The restaurant industry is facing its most severe test in recent years. To survive in difficult conditions, restaurant business owners are transforming their usual formats of activity and use all possible reserves and key resources.

Considering that at the current stage of development, the sphere of the restaurant industry is a global computerized business based 
on Internet technologies and alternative online services, in modern conditions they should be maximally involved in the activities of restaurant business enterprises.

Information technology today, more than ever before, is becoming an increasingly valuable resource in the restaurant business, helping restaurateurs not only maintain their viability, but also open new promising areas of development.

To preserve the business and ensure the effective reprofiling of the usual operating mode of restaurant business establishments in the format of targeted delivery of orders, a conceptual framework for marketing restaurant business enterprises in social networks is proposed, which integrates the key emphases of the value content in the pandemic.

Even in a stable situation, every restaurant, if it wanted to be competitive and profitable, had to do social media marketing, namely, have social media pages, a website, advertise on the internet, communicate with customers, encourage them to try new dishes and we are constantly working to increase the new client base.

\section{Bibliographic references}

Binsawad, M. (2020). Social media efficiency towards restaurant business: a comparison between social media profiles (case study in Saudi Arabia) Multimedia tools and applications. T 79. No. 41-42P. 389-399.

Dimitriou, CK., \& AbouElgheit, E. (2019) Understanding generation z's social decisionmaking in travel. Tourism and hospitality management-croatia, Vol 25(2), pp. 311-334.

DiPietro, RB, Crew, T.B., Gustafson, K., \& Strick, S. (2016). Using Social Media Sites in the Restaurant Business: Best Practices. Journal of Foodservice Research, Vol. 15, pp. 265-284.

Hajli, M.N. (2014). A study of the impact of social media on consumers. International Journal of Market Research, Vol. 56, pp 388-404

Hoferichter, N.A. (2018). Digital economy and restaurant business. In the collection: Economy and tourism in the XXI century: new technologies and innovations. Collection of scientific papers. St. Petersburg, pp. 68-70.

Kim, W.G., Li, J.J., \& Brymer R.A. (2016). The impact of social media reviews on restaurant performance: The moderating role of excellence certificate. International Journal of Hospitality Management. Vol. 55, pp. 41-51.

Lepkowska-White E., Parsons A., Berg, W. (2019). Social media marketing management: an application to small restaurants in the US.
International journal of culture tourism and hospitality research, Vol 13(3), pp. 321-345

Meagher, B. \& Cheadle, A. (2020). Distant from others, but close to home: The relationship between home attachment and mental health during COVID-19. Journal of Environmental Psychology, Vol 72(6), pp. 191-197.

Melnik G.S. (2020). The impact of online media on epidemics. Scientific works of the North-West Institute of Management RANEPA. Vol. 11, No. 3(45), pp. 57-58.

Mullakhmetova, R.Kh. (2020). Social networks in Russia: problems, features and development prospects. Innovations. Science. Education. No. 22, pp. 1909-1913.

Osipov, V.A., Shashlo, N.V., \& Kuzubov, A.A. (2017). Evaluation of economic sustainability of entrepreneurship on the basis of the valuebased efficiency theory. Espacios, Vol 38(62), C. 30.

Petrova D.A. (2020). Restaurant business in a pandemic. In the collection: Economy, governance and law in modern conditions. Interuniversity collection of articles. Togliatti, pp. 85-88.

Petruk, G.V., \& Shashlo, N.V. (2020). Formation of personnel intellectual activity development mechanism in the context of society digitalization. PalArch's Journal of Archaeology of Egypt/ Egyptology, Vol 17(6), pp. 708-718.

Rudskaya, E.N., Maksimenko, A.N., \& Desyatnichenko, L.V. (2019) Logistic engineering of business processes in the market of marketing services: Monitoring and control of promopersonal's work. Bulletin of the Altai Academy of Economy and Law, $\mathrm{N}^{\mathrm{o}} 3$, pp. 90-103.

Shashlo, N. V. (2017) Interaction system of the enterprise-integrator with infrastructural support subjects. Azimuth of Scientific Research: Economics and Administration, Vol 6. No 2(19), pp. 307-310.

Singh, R.K., \& Verma H.K. (2020). Influence of Social Media Analytics on Online Food Delivery Systems. International Journal of Information System Modeling and Design, Vol 11(3) SI, pp. $1-21$.

Taha, N. (2019). Impact of social media marketing on employee-customer interactions. Bulletin of the Belarusian State Economic University. No. 3(134), pp. 43-47.

Taneja, S., \& Toombs, L. (2014). Putting a face on small businesses: Visibility, viability, and sustainability the impact of social media on small business marketing. Academy of Marketing Studies Journal, Vol. 18, pp. 249-260.

Terenteva, T.V., Shashlo, N.V., \& Kuzubov, A.A. (2017). Conceptual approach to the process of strategic positioning of business entities of the 
fishing industry. Academy of Strategic Management Journal, Vol 16(S2), pp. 1-13.

Zhu, Y. Q., \& Chen, H.G. (2015). Social media and human need satisfaction: Implications for social media marketing. Business Horizons, Vol. 58, pp. 335-345.

Zueva, Z.V, \& Safronov, D.A. (2018). Media Marketing. Irkutsk University Bulletin. No. 21, pp. 182-183. 